E.L.U.A. 3, 1985-1986, págs. 7-46

\title{
LA TEORÍA LITERARIA DEL CONCEPTISMO EN BALTASAR GRACIÁN *
}

\author{
MARÍA TERESA HERNÁNDEZ \\ (Universidad Nacional de Educación a Distancia. Madrid)
}

La situación general del arte y la sociedad española en relación con el fenómeno conceptista culmina en una obra fundamental para comprender el arte del Siglo de Oro, la Agudeza y Arte de Ingenio de Baltasar Gracián, publicada, como se sabe, en 1642 y en su redacción definitiva, que es la que aquí tendré en cuenta, en 1648 '.

* Trabajo realizado por la autora como miembro del equipo de investigación sobre Teoria Literaria, siglos XVI-XVII, becado por la Fundación Juan March.

1 Cfr. para información general de los hechos relativos a Gracián y la Agudeza, el estudio de conjunto de Evaristo Correa Calderón, Baltasar Gracián. Su vida y su obra. Madrid, Gredos, 1970 (2." ed.), especialmente pp. 154-168, además de sus introducciones a la edición de las Obras completas, Madrid, Aguilar, 1944 y a la Agudeza y Arte de ingenio, Madrid, Castalia, 1969, 2 vols., que es la que manejamos nosotros. Aparte de otros estudios, ya clásicos y en muchos aspectos superados, como los de A. F. Bell, o de Vittorio Borghini, Baldassar Gracian, scrittore morale e teorico del concettismo, Milán, Ancora, 1947, son útiles: el resumen del informado especialista en este autor, Ricardo del Arco y Garay, Baltasar Gracián y los escritores conceptistas del siglo XVII, en Historia general de las literaturas hispánicas, Barcelona, Vergara, 1953, Vol. III, pp. 695 y ss.; así 'como las colecciones de estudios de dos destacados especialistas, M. Romera Navarro, Estudios sobre Gracián, Austin, Univ. Press, 1950; y Miguel Batllori, Gracián y el Barroco, Roma, Ediz. di Storia e Letteratura, 1958. Finalmente un estudio monográficamente dedicado al cotejo de las dos redacciones gracianescas de la Agudeza es el de A. Navarro González, Las dos redacciones de la "Agudeza y Arte del ingenio", en "Cuadernos de Literatura», 1948, IV, pp. 201-214. Sobre la extensísima bibliografia de Gracián disponemos de distintas exposiciones 
Los principales problemas del texto gracianesco han sido ya suficientemente abordados por la crítica ${ }^{2}$. Por ello nuestro actual interés en el examen de la Agudeza tratará de centrarse estrictamente en aquellos fenómenos sobre los que aporta novedad el examen de la tradición de conceptismo teórico, en cuanto que la Agudeza pueda suponer un colapso de las opiniones tradicionales, o por el contrario simplemente un paso más en la línea de su propagación ${ }^{3}$.

Adelantemos que a nuestro parecer se da absolutamente el segundo caso; es decir, la Agudeza de Gracián señala la salida natural de las opiniones tradicionales sobre el concepto. Pero, dicho esto, es preciso inmediatamente añadir que por ello no se trata de que juzguemos la Agudeza, como con relativa frecuencia se ha hecho, una obra menor, mostrenca, en el conjunto general de la producción gracianesca, ni en

como las de Romera Navarro y Arturo del Hoyo, actualizadas en la obra general citada de Correa Calderón.

2 Cfr. Ricardo de Arco Garay, La erudición aragonesa en el siglo XVII en torno a Lastanosa, Madrid, C. F. Archiveros, 1934; asi como los datos sobre la extensa lista de autores y citas contenidas en la Agudeza que nos proporciona Correa Calderón en su edición citada. En cuanto a sus relaciones con los teóricos italianos del conceptismo, Pellegrini y Tesauro, cfr. Benedetto Croce, I trattatisti italiani de/ concettismo e Baltasar Gracián, en Problemi di Estetica, I. Bari, Laterza, 1948; Adolphe Coster, Baltasar Gracián, Zaragoza, Inst. Fernando el Católico, 1947, traducción del trabajo aparecido en la "Revue Hispanique» en 1913, Edward Sarmiento, On two criticisms of Gracian's «Agudeza», en “Hispanic Review», 1935, III. 23-25. S. L. Bethell, Gracián, Tesauro and the nature of metaphysical wit, en «The Northern Miscellany of Literary Criticism». Manchester, 1953, I, pp. 18-40. M. J. Woods, Gracián, Peregrini and the theory of topics, en "The Modern Language Reviewn, LXIII, 1968, pp. 854-863. Finalmente el libro de A. García Berrio, España e Italia ante el conceptismo, Madrid C.S.I.C., 1968, pp. 45-135. En el aspecto de sus interesantes y curiosas peculiaridades críticas respecto a la literatura contemporánea son muchos los autores a quienes ha sorprendido el especial conceptismo de Gracián, que admite de mala gana a Quevedo y elogia hiperbólicamente a Góngora y a Marino; a este respecto recordaremos sólo la más sistemática y rica sintesis de Félix Monge. Culteranismo y Conceptismo a la luz de Gracián, en atiomenaje... para celebrar el tercer lustro del Instituto de Estudios Hispánicos... de Utrecht", La Haya, 1966, pp. 355-381. En torno al valor doctrinal de la obra, ya sea sobre hechos estrictamente técnicos, ya como en el caso de May, Maldonado de Guevara o Heger, tratando de conectar tales hechos con los más ocultos significados de Gracián, maestro de vida y síntoma de la España de su época. A todos estos trabajos nos iremos refiriendo posteriormente en el cuerpo de nuestro estudio.

3 Poco más que un somerísimo resumen de opiniones generales, escasamente conectado con los problemas de antecedentes estrictamente conceptistas, resulta ser el trabajo de título muy prometedor de Virginia Ramos Foster, Baltasar Gracián y los conceptos de la poesia antes de la "Agudeza y arte del ingenio", en «Hispanófila», 1969, n. ${ }^{\circ}$, pp. 33-43.

Véase de la misma autora, Nota sobre la «Agudeza y arte del ingenio" y la estética barroca, en «Rev. de Ideas Estéticas», XXVI, 1968, pp. 167-171. 
la tradición de teorías sobre el conceptismo. Antes bien, en esta obra el genio de Gracián se manifiesta en todo el valor de su agudeza doctrinal y su sentido de la oportunidad histórica. Del rasgo de ingeniosidad que, exhibido por distintos autores, en épocas diferentes y en facetas diversas, aparecia como un conjunto de inadvertidos hilos de agua dispersos, en muchos casos remansados y perdidos, llegamos a percatarnos sólo gracias a la incomparable perspicacia de Gracián de que se trataba en realidad de un gran torrente, en el que venía encauzado lo mejor de nuestro genio literario nacional ${ }^{4}$. Una dilatada tradición de agudeza, que arranca en el mundo clásico con un hito insuperable para el jesuita aragonés, su paisano Marcial, y que por medio de los «agudos antiguos españoles" conocidos por él a través del Cancionero General, se extiende a lo ancho de los siglos XVI y XVII, y alcanza a todos sus contemporáneos sin distinciones, culteranos o conceptistas. De esta forma, la imagen de la conceptuosidad que nos ofrece la Agudeza, coincide plenamente con el sentido de nuestra investigación '. La agudeza, el gusto por el concepto, era a juicio de Gracián tan connatural con el espíritu español en el momento en que reflexiona sobre nuestras letras, que no halla otra cualidad mejor para caracterizar y ensalzar el talante peculiar de los ingenios de su patria. Así lo proclama orgullosamente:

«En España siempre hubo libertad de ingenio, o por gravedad, o por nativa cólera de la nación, que no por falta de inventiva. Sus dos primeros ingenios, Séneca en lo juicioso y Marcial en lo agudo, fundaron esta opinión, acreditaron este gusto. Prudente aquél, nunca pudo sujetarse a los rigores de un discurso, a la afectación de una traza; y si los émulos apodaron arena sin cal... el raudal de su doctrina, los apasionados lo aclamaron por gravedad española, opuesta en todo a los juguetes de la invención griega" 6 .

4 Entre los estudios generales que afirman estas consideraciones sobre la Agudeza recordemos: Schalk. Baltasar Gracián und das Ende des Siglo de Oro, en wRomanische Forschungen", LIV, 1940, pp. 282-283; y LV, 1941, pp. 113-127; K. Vossler, Introducción a Gracián, en «Rev. de Occidente», XLIX, 1935; y E. Correa Calderón, Baltasar Gracián, su vida y su obra, cit.

5 Una extensa reseña de la agudeza en los escritores latinos se halla, aparte las numerosísimas alusiones dispersas en la obra, en Agudeza, ed. cit., Vol. II, pp. 235-242. Respecto de los antiguos poetas españoles del XV, véase singularmente Vol. I, pp. 252-254.

6 Ibid, Vol. II, pp. 168-169. 
En las líneas anteriores se puede advertir -además de la decidida afirmación, por otra parte tópica, sobre la condición connatural del ingenio con lo hispánico, contrastada ya desde sus primeras manifestaciones con no poca ligereza a los «juguetes de la invención griega»una precisa caracterización del concepto en el ánimo de Gracián como elemento claramente correspondiente al tipo de pieza fragmentaria. $\mathrm{Pa}$ rece, en los términos en que Gracián se pronuncia, que toda nuestra literatura se compone de pequeñas piezas ingeniosas y que en ella son raros e innaturales los primores de la "agudeza compuesta", las estructuras imaginarias extensas. No cabe duda de que objetivamente el Quijote, La Dorotea, o el Buscón, serían tres excepciones entre centenares a tan extremosa afirmación; pero lo evidente es que de esta manera apreciaba el conjunto de nuestras letras el interés de un español de 1640 como Gracián, totalmente deslumbrado por la conciencia de conceptuosidad reinante.

Si esas palabras de Gracián hacian alusión a una problemática situación lejana, juzgando la más próxima y contemporánea, el aragonés muestra su inalterable opinión; y esta vez diriamos que en términos indiscutibles y más ajustados a la realidad:

"Quedó vinculado este gusto (que no le llamo -dice Gracián con genial oportunidad y distanciamiento- absolutamente acierto) en esta ingeniosa provincia, hermosa cara del orbe, y nunca más válido que en este feraz siglo, en que han florecido sus ingenios con su dilatada monarquía, discurriendo todos a lo libre, asi en lo sacro como en lo profano"?

Pero, ¿en qué consistía exactamente según Gracián la esencia de ese artificio, el concepto, tan continuamente aludido desde hacía más de cincuenta años como escasa y variamente caracterizado? Al fin, con la Agudeza, disponemos del documento que con precisión y autoridad genial define lo que había sido una constante observada generalmente en la tradición anterior: el concepto - en una primera caracterización esencial- se ve vinculado indiscutiblemente a lo que hoy llamariamos el «plano del contenido». De los cientos, quizá millares, de apariciones del término en la obra de Gracián ese resulta ser el rasgo común del concepto, su valor fijo. Una muestra bastará, en la que aparece aludido concepto en un contexto y acepción claramente acordes con su uso tradicional como sinónimo de pensamiento. Hablando de los jeroglíficos, emblemas y empresas afirma:

7 Ibid., Vol. II, p. 169. 
"Corta esfera le parece a la fecunda invención la de palabras y de escritos cuando pide prestados - la poesia - a la pintura sus dibujos para exprimir sus conceptos" *. En relación con tal carácter podríamos citar numerosos lugares de la Agudeza donde se cita pensamiento como sinónimo de concepto. Así, comentando un símil claramente conceptuoso de Lucano sobre la situación histórica contemporánea en relación con la rebelión de los gigantes contra Júpiter, exclama: «... es grande el pensamiento, y de los de primera clase». Y la misma actitud podríamos advertirla muchas otras veces".

Pero lo dicho hasta aquí de Gracián, aunque supone una verificación fundamental para conectar su doctrina con el estado de opinión más generalizado en la tradición-ambiente conceptuosa, no descubre en verdad nada nuevo a la opinión actual en torno a la interpretación de la génesis ingeniosa del concepto. Correa Calderón, por ejemplo, define el concepto gracianesco como «pensamiento artificiosa e ingeniosamente expresado" " 10 . Sólo Benedetto Croce apuntó hacia una solución distinta, que vinculaba más bien el concepto, como fenómeno de puro ornato - figura retórica-, con la expresión; pero la contundente refutación de Sarmiento cortó definitivamente cualquier iniciativa en tal sentido ".

Sin embargo la perspicacia de Gracián enriquece esta nota inicial del concepto añadiéndole las de sutileza, agudeza, etcétera, que, de algún modo, en determinados fragmentos, podrian inducir a un lector poco avezado en el conocimiento del sistema de ideas literarias de Gracián a formarse una opinión similar a la que acabamos de aludir en Croce.

Cualquier pensamiento no adquiere la condición de concepto, sino aquel que ha sido elaborado con ponderación ingeniosa, aquel que sorprende con su agudeza, aquel, en definitiva, que manifiesta un claro artificio, un voluptuoso deleite en su consecución.

Nada mejor para ilustrar lo expuesto que acudir a la génesis del concepto en el ya de sobra establecido sistema de correlaciones gra-

8 Ibid., vol. II, p. 212.

9 Ibíd., Vol. I, pp. 102, 114, 129, 240 («tienen estos pensamientos de sutiles y primorosos to que tienen de metafísicos»), 258 , etc... etc...

10 Cir. E. Correa Caiderón, introducción a su edic. cit. de la Agudeza, Vol. I, p. 26.

11 Cfr. B. Croce, I teorici italiani del concettismo e Baltasar Gracian, cit. y E. Sarmiento, On two criticisms of Gracián's «Agudeza», cit., p. 26. 
cianescas. El pensamiento no conceptuoso procede del juicio, mientras que el concepto propiamente dicho reside en el ingenio, capacidad del entendimiento como la anterior, caracterizada frente a aquélla por perseguir la hermosura y no primordialmente la verdad:

«No se contenta el ingenio - decia Gracián- con sola la verdad, como el juicio, sino que aspira a la hermosura..." «De aquí se saca con evidencia - había dicho unas líneas más arriba-, que el concepto, que la agudeza, consiste también en artificio, y el superlativo de todos...» ${ }^{12}$.

Sin embargo el ingenio actúa, en cuanto virtud, a través de la agudeza. Asi lo expone Gracián al comienzo mismo de su obra: «Hallaron los antiguos métodos al silogismo, arte al tropo; sellaron la agudeza, o por no ofenderla, o por desahuciarla, remitiéndola a sola la valentía del ingenio" "'. La agudeza aparece caracterizada en Gracián como virtud resultante, potencialidad y actividad, y no como resultado último formulado. Aunque a veces, a causa de esa fluctuación terminológica que hemos observado tantas veces ya en esta resbaladiza y tópica doctrina, resulten contextos que la refieren a una condición de «ergon». Pero dichos ejemplos, si es que puede hallarse alguno que lo sea indiscutiblemente, serian insignificantes frente a la práctica normal de definir agudeza como «energía» 14.

Indudablemente, este error no se produciría si se tomara como base el uso habitual, vulgar, de los términos, tal como puede apreciarse en numerosos ejemplos de la situación precedente en España e Italia ${ }^{15}$. Pero en el caso de Gracián el término y su contenido están rigurosa-

12 Cfr. Agudeza, ed. cit. Vol. I, p. 54.

13 Ibid., Vol. I, p. 47

14 Cfr. Adolphe Coster, Baltasar Graclán, ed. cit., que cayó entre otros muchos en este ingenuo error, del que le acusa Sarmiento: "Although it is true that Gracian -hablando de un punto concreto de su obra- is not so consistent as we could wish, there does seem to be a definite tendency to take agudeza as the faculty, and concepto as the exemplification. the individual result". Cfr. E. Sarmiento, On Two Criticisms..., cit., pp. 30-31. Algunos lugares en los que el contexto podria acercar agudeza al valor resultado de concepto, si bien en ninguno de ellos pueden ser asimilados absolutamente, se hallan en Vol. 1, pp. 50, 141, 144, $152,154,180,254$, etc... etc...

15 Quizá el error de Coster se deba sobre todo a la supervivencia de la acepción extendida en Italia hacia 1639 y que se manifiesta ya en el titulo de la obra de Mateo Pellegrini, que debia estimar mucho el crítico francés para valorarla en tantos aspectos sobre la Agudeza misma. Recordemos el referido titulo, Delle acutezze, che altrimenti, Spiriti, Vivezze e Concetti vulgarmente si apellano. Genova, C. Ferroni, MDCXXXIX. 
mente empleados y delicadamente insertos en un equilibrado sistema de correlaciones conceptuales. Resplandece una vez más la diferencia doctrinal que media entre el libre manejo, casi popular, de términos y conceptos que estaba en el ambiente, y la ponderada sistematicidad con que definitivamente los caracterizó Gracián.

Por consiguiente no basta a la vista de la doctrina general de la obra algún contexto más o menos explícito, que vincule ocasionalmente concepto a alguna facultad o potencia diferente de agudeza o ingenio, para enfrentar agudeza y concepto como resultados en el mismo nivel de causas diferentes ${ }^{16}$.

Por supuesto que en el rico repertorio terminológico de Gracián pueden encontrarse a veces formas especialmente apropiadas para definir operaciones muy concretas. Pero si no nos prevenimos contra tan exquisitas y variables precisiones, corremos el peligro de confundir los principios más esenciales por los que se rige la agudeza gracianesca ${ }^{17}$.

16 Creo que esto ha sido en alguna ocasión lo que ha motivado la generalización peligrosa del sentido de agudeza a que hago alusión. Por ejemplo, en el caso del informado crítico gracianesco T. E. May: "There is one single act of mind expressed in the conceit, of which agudeza and concepto are aspects: concepto corresponds directly to entendimiento, agudeza to ingenio. Ingenio becomes a power of understanding to act artistically to trasform its own object harmoniously; the agudeza is the result of exercise of this power; concepto therefore has to be thought of as the understanding's essential act gasping reality now auto-transformed by being involved in agudeza». Cfr. T. E. May, Gracian's idea of the "concepto", en shispanic review», 1950, XVIII, pp. 15-41; el texto citado en p. 21. Evidentemente, entendimiento alude por igual como primer motor a juicio y a ingenio, asi como a todas sus facultades y operaciones derivadas. Por esto decía que no era contradictoria la asociación de concepto a entendimiento y no a juicio, por una parte, o a sus derivados ingenio y agudeza por otra. Sin embargo enfrentar en principio, en los términos que May lo hace, concepto a agudeza deja en libertad al juicio, que parece asociai al concepto una base intelectual no artificiosa frente al carácter totalmente artificioso y elaboradamente ingenioso de agudeza. Sin embargo al final del texto copiado, el propio May restituye la claridad sobre la naturaleza ingeniosa del concepto, cuando habla de la autotransformación de la realidad conceptualizada bajo la manipulación de la agudeza. Si concepto se relaciona genéricamente con entendimiento en la más famosa y clara definición gracianesca del mismo, Ibíd., Vol. I, p. 55, lo mismo que a la mente en otros lugares "hijos del esfuerzo de la mente", Ibid., Vol. l, p. 47, resulta obligado en mi opinión por las consideraciones expuestas en el texto entender tales entendimiento y mente como principios fundamentales a los que seguirían todos los demás: juicio, ingenio, agudeza, concepto, etc., por vías muy diferentes. Más aclarador sobre el valor ingenioso que Gracián comunica al concepto en su obra, me parece caracterizarlo con toda claridad como producto, resultado de la actividad de la ingeniosa agudeza obrando selectivamente en los pensamientos simples, productos del juicio.

17 Klaus Heger, sobre los problemas de la traducción gracianesca de Schopenhauer, nos ha prevenido contra este importante riesgo, al distinguir con precisión entre significación estructural de las palabras clave y significación semántica, variable en cada contexto: 
Así sucede, por ejemplo, a Sarmiento, cuando se deja llevar por el atractivo y sugestión del término especializado perspicacia:

«Perspicacia in Gracian is the flair for perceiving material for the conceit, artificio is the capacity for constructing it, or sometimes, the conceit itself»... "Perspicacia is to Gracian's juicio what ingenio (and its synonymous) is to entendimiento" ${ }^{1 \times}$.

Juzgo por tanto como positivo y prudente no aventurarme en profundas precisiones sobre la terminología de Gracián, ya que, más poderosa aún que su sagacidad para producir esta densa variedad taxonómica, era su voluntad de fluctuación general terminológica. Desconocer la necesaria generalidad de los términos ingenio y agudeza en la obra de Gracián es sin duda peligroso. Si perspicacia, artificio y otros tecnicismos similares se presentan como capacidades actuantes en el ámbito limitado de la agudeza de concepto, no hay que olvidar que en fin se trata de causas inmediatas, las cuales se subordinarán a su vez a la gran causa mediata y general que es la agudeza, y a la capacidad motriz del arte barroco que es el ingenio. En este sentido me identifico con la opinión de Klaus Heger, para el cual el ingenio ocupa la función de mediación artístico-literaria entre la posición intelectual del juicio y la puramente retórica del gusto verbalista ${ }^{19}$.

La profundización en la naturaleza intelectual y contenidista del concepto que se percibe en toda la obra de Gracián es un hecho que no debemos olvidar. El concepto es fruto de la actividad ingeniosa de la agudeza, que se desarrolla en el área estricta de los contenidos intelectuales en la producción literaria; pero eso no quiere decir que la agudeza no actúe igualmente en otros ámbitos, el verbal o el de las acciones, que en principio aparecerán como espacios no propiamente conceptuosos. La insistencia de Gracián en marcar la especialización ingenioso-intelectual del concepto cristaliza en numerosos testimonios

\footnotetext{
«La otra - consecuencia - consiste en las palabras - por lo menos un gran número de palabras clave - obtiene asi una importancia estructural dentro de la obra gracianesca que les presta una significación por encima de su valor semántico, una significación estructural fija que contrasta con lo oscilante de su significación semántica». Cfr. Klaus Heger, Genio e ingenio, en «Revista de la Universidad de Madrid", 1958, VII, N. ${ }^{\circ} 27$, pp. 379-401; el texto en p. 381.

18 Cfr. E. Sarmiento, On two Critıcisms..., cit., pp. 32-33.

19 Cfr. Klaus Heger, Baltasar Gracián. Estilo y doctrina, Zaragoza, Instit. Fernando el Católico, 1961, p. 182: «... en cuya polaridad —en la que se halla el ingenio-se expresa una contraposición de pensamiento racional e ideas irracionales".
} 
a lo largo de la Agudeza. Ambos componentes, el artificio y el fondo intelectual, destacan por ejemplo en la descripción de las etapas preconceptistas del arte literario: “Eran los conceptos hijos más del esfuerzo de la mente que del artificio, pero grandes". En otros lugares se asocia agudeza y concepto como operaciones, o resultados, del entendimiento: «Entendimiento sin agudeza ni conceptos, es sol sin luz, sin rayos". Finalmente en esta otra ocasión en la que ya sólo aparece aludido el concepto como fruto del entendimiento: «... lo que es para los ojos la hermosura, y para los oídos la consonancia, eso es para el entendimiento el concepto" ${ }^{20}$.

La agudeza en el plano expresivo crea y selecciona esquemas lingüisticos maravillosos; se desvincula de las operaciones propiamente conceptuosas para convertirse en agudeza retórica. La constancia de Gracián también en estas observaciones no desdice de su insistencia antes aludida en destacar la naturaleza intelectual del concepto. Ya lo advertía claramente Gracián desde su prefacio al lector:

«Válese la agudeza de los tropos y figuras retóricas, como de instrumentos para exprimir cultamente sus concetos, pero contiénense ellos - los tropos- a la raya de fundamentos materiales de la sutileza, y cuando más, de adornos del pensamiento" "I.

Insistiendo en esta declaración general, en el comienzo del Discurso $X$, dedicado a tratar "De las semejanzas conceptuosas", expone con claridad la diferencia entre artificio conceptuoso y artificio retórico.

«No cualquiera semejanza (en opinión cie muchos) contiene en sí sutileza, ni pasa por concepto, sino aquéllas que incluyen alguna otra formalidad de misterio, contrariedad, correspondencia, improporción, sentencia, etc. Éstas, dicen, son objecto desta arte, incluyen, a más del artificio retórico, el conceptuoso, sin el cual no serían más que tropos o figuras sin alma de sutileza» 22 .

El artificio conceptuoso actúa, precisamente, porque profundiza en los términos intelectualmente contrapuestos en el simil, que asi pasa de ser esquema retórico, tropo, a convertirse en concepto: «Pero cuando a

20 Cfr. Agudeza... ed. cit., Vol. I, pp. 47 y 50-51.

21 Ibid., Vol. I, p. 45.

22 Ibíd., Vol. I, p. 124. 
la semejanza da pie alguna circunstancia especial del sujeto a quien se arguye, entonces es rigurosamente concepto, y de semejanza retórica pasa a sutileza del ingenio" ${ }^{23}$. De manera equivalente se expresa Gracián cuando trata del concepto opuesto por desemejanza: "Las conceptuosas, y que son rigurosamente conceptos, son las que se fundan en alguna circunstancia especial, tomando pie della el discurso para conceptear, y entonces, a más del artificio retórico, añaden el conceptuoso". $Y$ en general en todas las ocasiones paralelas que se van ofreciendo en cada discurso ${ }^{24}$.

Observamos por tanto que Gracián atribuye a la ponderación intelectual de las circunstancias, de donde sale la formulación ingeniosoconceptuosa, la esencia del artificio conceptista. Por ejemplo, a propósito de las "ingeniosas transposiciones", la naturaleza "crítica» del objeto tratado - según Gracián elaboración intelectual de naturaleza peyorativa respecto al objeto glosado, en oposición a la agudeza panegírica-puede venir a producir ese acrecentamiento de circunstancias sobre la base intelectual del puro esquema retórico, que da al producto la condición ingeniosa con la que adquiere la naturaleza de concepto:

"Todos los conceptos que se fundan en la crisi son más gustosos, porque se añade a lo picante del artificio lo picante de la materia, y así, esta sutileza del transformar las cosas, cuando es critica, es extremada». Y lo mismo sirve, por ejemplo, para la que Gracián denomina la agudeza paradoja: «Para el concepto paradojo se requiere también el fundamento de alguna circunstancia especial, que favorezca y dé ocasión al extravagante discurso». Igualmente a propósito de la agudeza crítica y maliciosa: "Siempre que da pie al concepto alguna circunstancia especial, es más sutil por lo fundamental y porque se hace ingeniosamente el reparo sobre la especialidad della» 25 .

El concepto resulta ser un elemento correspondiente al ámbito del contenido o del pensamiento, con lo que se diferencia de las figuras retóricas; pero a causa de su elaboración artificiosa, por la agudeza que

23 Ibíd., Vol. i, p. 140

24 Ibíd., Vol. 1, p. 145. Véase otra muestra en el Discurso XVI De los conceptos por disparidad: «Requiérese también, para que la disparidad sea conceptuosa y se realce a más que primor retórico, alguna circunstancia especial, que dé pie y sea fundamento de la agudeza». Ibid. Vol. I, p. 171

25 Ibid. Vol. I, pp. 186, 226 y 262 , respectivamente. 
testimonia, se diferencia también de los productos normales del entendimiento elaborados por el juicio. El carácter selecto del que este peculiar pensamiento, el concepto, aparece adornado, se manifestará legularmente en las mismas fórmulas idiomáticas con que Gracián lo caracteriza en su Agudeza 26 .

Aporta igualmente claridad el análisis del valor estructural de elementos tan significados en la producción de conceptos como son sutileza y ponderación. Los dos términos, entre otros no menos notables, son enumerados como resultados conceptuosos: «Esta urgencia de lo conceptuoso, es igual a la prosa y al verso. ¿Qué fuera Augustino sin sus sutilezas y Ambrosio sin sus ponderaciones, Marcial sin sus sales y Horacio sin sus sentencias?" ${ }^{27}$. Sin embargo, fuera de contextos claros como el anterior, resulta difícil delimitar en la Agudeza si se trata de un elemento adjetival, la sutileza de un concepto, lo que por tanto daria a sutileza su valor de virtud productiva; o bien si es, por el contrario, un testimonio acabado de esa virtud. Véase en concreto sobre sutileza, el fragmento siguiente a propósito de unos versos latinos del jesuita Remondo:

«Entretéjense aquí muchas sutilezas; el reparo en las contingencias, la contraposición entre las mismas, y concluye con la ingeniosa similitud. Cualquiera de las circunstancias, o adjuntos del sujeto disimilado, da pie con artificiosa sutileza para la diversi$\mathrm{dad} » 2 \mathrm{k}$.

El segundo de los términos, ponderación, aclara también este mismo ejercicio de elaboración artificiosa de la base intelectual del

26 Contrastar algunos contextos ilustrativos: "para exprimir cultamente sus concetos", I, p. 45: «... $\tan$ valiente conceto», I, p. 46; «... tan hechos a las delicias del concepto, que no pasan otro que sutilezas", l, 49; «...cisne en los concentos, águila en los conceptos", I, p. 79; «concepto de primera magnitud", I, 108; «grandes conceptos», I, 122; «augusto concepto", I, 123; “...porque aspirase a sobrehumano su concepto", I, p. 165; «... la extremada improporción, que hace más picante el concepto", 1,267 , etc... etc...

27 lbid. Vol. I. p. 51.

28 Ibid. 1. p. 146. Otros casos de ambigua contextuación, que creo aluden a la acepción del término como capacidad, en Vol. I, p. 163; I, p. 124: “No cualquiera semejanza contiene en sí sutileza...", etc... Mientras otros ejemplos ofrecen más claramente la acepción de resultados, sinónimos más o menos rigurosos de concepto; por ejemplo: «Pero cuando a la semejanza da pie alguna circunstancia especial del sujeto a quien se arguye, entonces es rigurosamente concepto, y de semejanza retórica pasa a sutileza del ingenio", l, p. 140 , igualmente l, p. 154 , etc... 
concepto. La denominación fue muy empleada por Gracián, aplicada generalmente a la descripción de un proceso. Igual que en otros casos realmente claves como sutileza o agudeza, se ofrece en determinados contextos bajo una expresión tan ambigua que no se puede descarta? en sí misma tampoco como forma de designar el resultado de ese mismo proceso ${ }^{29}$. Alternando en su designación como ponderación o como encarecimiento ${ }^{30}$, Gracián adelanta la duda de si se trata de una simple expresión hiperbólica, y por tanto de una figura y no de un concepto:

«Son los tropos y figuras retóricas materia y como fundamento para que sobre ellos levante sus primores la agudeza, y lo que la retórica tiene por formalidad, esta nuestra arte por materia sobre que echa el esmalte de su artificio. No pasan algunos por concepto el encarecimiento asi a secas: dicen no ser más que un hipérbole retórico, sin el picante de la agudeza viva y verdadera».

Sin embargo cuando se aplica sobre la base del pensamiento conceptuoso, para aumentar los elementos metafóricos que caracterizan el más común y puro tipo de conceptos, la ponderación se hace actividad señaladamente conceptuosa, elemento intensificado. A esta descripción, a la que corresponde el empleo más habitual en la Agudeza de los términos ponderación y encarecimiento, se añade en el mismo discurso del texto anterior el siguiente fragmento, donde Gracián disipa los reparos antes expuestos a condición de introducir la hipérbole retórica como auténtico proceso artificioso:

"Cuando en el reparo hay dificultad o llega a contradicción, sale mejor el desempeño por un encarecimiento. Fue gran concepto de Marcial con que cantó la quema del Fénix de la amenidad, el Vesubio" ${ }^{3 t}$.

29 He aqui algunos ejemplos: «Por grande que sea el término del careo, no se juzga bastante tal vez, si bien se le concede alguna sombra de paridad, que es ingenioso encarecimiento, como éste", I, p. 167; en este otro parece abrirse más bien la acepción más rara y antisistemática de resultado; «Fórmase de ordinario el encarecimiento, ensalzando el objecto y ponderando su exceso, en sí o en alguna de sus circunstancias", I, p. 198; etc... etc... Consúltese de modo especial el Discurso XXII, dedicado al tratamiento «De las ponderaciones juiciosas, críticas y sentenciosas por exageración", pp. 220-224.

30 Consúltense los Discursos $\mathrm{XX}$ y XXI, dedicados especiaimente al tratamiento del encarecimiento.

31 lbid. Vol. I, pp. 204 y 210 , respectivamente. 
Según va apareciendo, el concepto como elemento marcadamente artificioso, encuentra su verdadera esencia en un nuevo sentido del arte. Frente a la simple condición intelectual del contenido de las obras tradicionales proporcionada por las vías más directas, el concepto fomenta artificiosamente la complejidad del pensamiento aportado. No se trata de ponerlo al servicio de un arte críptico, intransitivo, fin en su propia expresión; sino por el contrario, de que se afirme sobre las bases de una fuerte conciencia didáctica, convencida de la necesidad de renovar las vias ya demasiado gastadas del arte, como puente entre el hombre y la realidad circundante. Lemas tan conocidos de Gracián no deben ser olvidados nunca para perfilar el valor último que su autor atribuye a la palabra-clave de concepto:

«... quien dice misterio, dice preñez, verdad escondida y recóndita, y toda noticia que cuesta, es más estimada y gustosa". "Cuanto más escondida la razón, y que cuesta más, hace más estimado el concepto, despiértase con el reparo la atención, solicítase la curiosidad, luego lo exquisito de la solución desempeña sazonadamente el misterio" ${ }^{32}$.

En esta tensión entre deformación y rectificación de la visión de la realidad insisten con distintas variantes desde Ortega y Gasset a T. E. May o Klaus Heger, todos los intentos profundos de explicar el Barroco artístico y a Gracián en concreto. Hipótesis sin duda atractivas, pero que aquí quisiera mantener alejadas de mis análisis teórico-literarios actuales ${ }^{33}$.

32 Ibíd., pp. 88 y 96. Pueden añadirse muchas otras formulaciones en la gama de confesiones sobre el sentido del nuevo arte que llenan la Agudeza, como ésta: "La verdad, cuanto más dificultosa, es más agradable, y el conocimiento que cuesta, es más estimado. Son noticias pleiteadas, que se consiguen con más curiosidad, y se logran con mayor fruición que las pacíficas. Aqui funda sus vencimientos el discurso y sus trofeos el ingenio". Vol. I, p. 99.

33 En dos sectores se han clasificado estas explicaciones "profundas" del contenido gracianesco. El primero busca en el estilo la traducción de una base ética -frente a viejas acusaciones del apasionado Coster- reconocida por la autoridad del buen gracianista Correa Caiderón, quien hablando de la Agudeza afirma: uresponde este tratado a sus predilecciones de la edad juvenil —que ratificará o rectificará en su madurez- sin que podamos pensar que fue un mixtificador, que daba una importancia secundaria a sus doctrinas, como supone Coster». Cfr. E. Correa Calderón, Sobre Gracián y su «Agudeza y arte de ingenio», en "Revista de Ideas Estéticas», 1944, VI, pp. 73-87; p. 86. Dentro de esta misma tendencia el libro de Klaus Heger, Baltasar Gracián, estilo y doctrina, ed. cit., aportó un rigor difícilmente superable para la crítica gracianista. Completan esta consideración, entre 
El concepto como entidad antirretórica se establece así en el sis* tema estético de Gracián como elemento acusadamente intelectual del mensaje literario, en el ideal de un arte básicamente transitivo, que nc elude la dificultad del mensaje pero que tampoco la ama en sí misma: Se renueva la reactivación de la doble dimensión, didáctica y deleitosa, con que se adorna el arte en sus expresiones de más puro equilibrio clasicista. Conceptismo en el más propio sentido del término; concibiendo al intelecto activado por la agudeza en la búsqueda de los contenidos más ilustrativos por ser los más sorprendentes e inéditos. Arte de ingenio cuyos resultados, los conceptos, no desmienten jamás, por encima de lo que pueda sugerir algún contexto aislado u ocasional,

otros, los conocidos estudios de M. Romera Navarro, Sobre la moral de Gracián, en «Hispanic Review», III, 1935, pp. 119-126; M. Hafter, Gracian and Perfectum: Spanish Moralists of the Seventeenth Century, Cambridge, Mass., Harvard Univ. Press, 1966; y sobre todo la obra definitiva, con la de Heger, de W. Krauss, Gracian Lebenslehre, Frankfurt, Klostermann, 1947.

Una segunda vía trata de conducir hacia razones ambientales, de cultura y patria, la interpretación profunda del pensamiento estilístico de Gracián; recordando a este respecto interpretaciones españolas agudas como la de José Luis L. Aranguren, La moral de Gracián, en «Revista de la Universidad de Madrid" 1958, VI, pp. 331-354: «La Filosofía del período es en su elaboración concreta, pura filosofía de acepciones, de juegos de palabras". Hemos de recordar sobre todo el esfuerzo de T. E. May en su primera aproximación, An interpretation of Gracian's "Agudeza y Arte de ingenio", en "Hispanic Review", 1948, XVl, pp. 257-300. Con la nueva actitud de búsqueda que significa su ya citado artículo Gracián's Idea of the concepto, May trata de fundamentar su explicación en el generalizado testimonio del cambio de óptica con razones elocuentes: «Gracian still assumes a given ordered universe, in which the mind has full freedom to act; and its acts are single acts. The unity in experiencie... He sees differently to us; and perhaps not altogether worse", p. 19. Deformación optica que corresponde a las vehementes necesidades del artista, ser en rebeldía, con la imagen del mundo que le proporciona el pasado, en la cual quiere descubrir nuevos perfiles correspondientes al sentido de su inquietud con una modalidad de poesia que es a la vez exploración y creación: "The self-sufficient mind imposes its own criteria of clarity or economy -in Gracian's case of aesthetic harmony - upon a nature which becomes correspondingly passive before its operations; and which, in revenge, begins to show itself as a jealous keeper of its own secrets", p. 23. Esta fórmula culmina magistraimente en el fragmento de El Criticón tan oportuna y bellamente traido a referencia por May, en el que Critilo, hablando de la caprichosa disposición de las estrellas, apunta como explicación que gracias a ella "cada uno proporciona las estrellas como quiere", May tratará de extenderla a síntoma de la época y del país con certeza siempre muy problemática en este tipo de especulaciones, pero con indiscutibles coherencia y elegancia.

Consecuencias proximas a tal actitud son examinadas, en campos muy distintos, por $\mathrm{J}$.

Fernández Montesinos, Gracián o la picaresca pura, en «Cruz y Raya», 1933, n. ${ }^{\circ}$, pp. 39-63; y por M. Baquero Goyanes, Perspectivismo y sátira en «El Criticón", en «Homenaje a Gracián", Zaragoza, 1958, pp. 27-56. 
su dependencia del gran motor de la universalizada agudeza barroca que es el ingenio ${ }^{34}$.

Sobre todo el más objetivo testimonio de lo que Gracián pensaba sobre la relación concepto-agudeza, nos lo ofrece él mismo; y no en contextos ocasionales elegidos directamente para aclarar el problema, entre los cuales los hay del más variado tenor; sino acudiendo a la extensa estructura Ilena de coherencia y equilibrio en la que Gracián traza el fundamento doctrinal de su obra, la clasificación de la agudeza. Partiendo de la agudeza como principio o virtud fundamental de toda labor de entendimiento, que considera por igual en estos primeros estadios los derechos de creación artística y los datos de verdad científica, Gracián califica como igualmente dotadas de agudeza, aunque marcando la profunda diferencia de sus productos, la actividad del juicio que ha de revelar la verdad, y la del artificio ingenioso descubridor de la hermosura sutil:

"La primera distinción sea entre la agudeza de perspicacia y la de artificio; y ésta, es el asunto de nuestra arte. (Se comprenderá aquí la necesidad de que hablábamos antes, a partir de formulaciones algo imprecisas de Sarmiento, de no matizar suficiente y terminantemente en la separación entre el concepto y la perspicacia, considerado como mera consecuencia de ésta y no de la agudeza ingeniosa; en tal caso, por declaración propia, el concepto quedaría fuera del interés del «arte» de Gracián). Aquélla tiende a dar alcance a las dificultosas verdades, descubriendo la más recóndita. Esta, no cuidando tanto deso, afecta la hermosura sutil; aquélla es más útil, ésta deleitable; aquélla es todas las Artes y Ciencias, en sus actos y sus hábitos; ésta, por recóndita y extraordinaria, no tenía casa fija» ${ }^{35}$.

Insistiendo todavía más en el sentido de nuestras palabras. hemos de señalar que el concepto no es agudo con agudeza científico-

34 Coincidimos completamente sobre esta estimación con el juicio hecho por Correa Calderón, quien, desarroliando las repercusiones semánticas de un verbo tan propiamente gracianesco como exprimir, definía el concepto como resultado inmediato o remoto de la capacidad del ingenio desplegado como agudeza artificiosa: "... el concepto es un producto del intelecto estrujado hasta el maximum, a fin de lograr las más forzadas asociaciones de ideas, la agudeza, que sería algo asi como un licor exquisito, un elixir, obtenido de esa presión y esfuerzo cerebrales puestos al servicio de la poesiam. Cfr. E. Correa Calderón, Sobre Gracián y su «Agudeza y arte de ingenio», cit., p. 78.

35 Ibid. Vol. I, p. 58. 
intelectual pura, de perspicacia; sino con agudeza eminentemente artística, de artificio. Sobre este punto del razonamiento de Gracián es particularmente necesario prestar atención, y más en el momento de valorar la función estricta de la perspicacia y del artificio en la constitución íntima del concepto. Es decir, de los elementos científico-intelectual e intelectual-artístico que concluyen en él, el segundo es el que verdadera y definitivamente lo configura y caracteriza.

El concepto como hecho artístico puro y centro esencial del arte tal y como lo concibe Gracián, llena de su condición intelectual como producto del entendimiento la fisonomía del arte gracianesco, donde la sutileza se abre el camino más válido en el plano de selección de las bases y en la elaboración posterior de los elementos de contenido. Por ello el concepto es tan intelectual como el mismo arte conceptista en su conjunto, pero sobre todo es artístico, es un difícil experimento humano, con el propósito de producir y descubrir belleza.

Por eso las otras dos modalidades de la agudeza artística o de artificio, la agudeza verbal y la agudeza de acción, no merecieron nunca para Gracián el rango de eminencia de la primera clase en la elaboración del arte que codificaba en su Agudeza, aun cuando las considerara también objetos estimables desde el punto de vista de su dimensión artística.

Resumiento en fin los hechos hasta aqui analizados, advertiremos que, en relación a la idea generalizada dentro de la imagen tradicional sobre el concepto, Gracián expone una opinión de naturaleza indiscutiblemente intelectual, carácter éste que decide la totalidad del arte conceptuoso. Pero la verdadera esencia de su condición artística viene dada al concepto en último término por la actuación sobre él del ingenio, comunicado como agudeza de artificio ${ }^{36}$.

Establecidas ya las doctrinas precedentes, podemos considerar aqui la naturaleza del artificio determinante del concepto. Ya sabemos,

36 Definia la agudeza verbal como la uque consiste más en la palabra; de tal modo que si aquélla se quita, no queda alma, ni se pueden éstas traducir en otra lengua". tbid., Vol. I, p. 58. Tal caracterización, si recordamos por ejemplo el menosprecio de Gracián por el maestro de este tipo de agudezas, Quevedo, no añade ninguna duda sobre la condición secundaria de tal clase de recursos artísticos en opinión de Gracián. A mayor abundamiento se citarian los resultados del tercer tipo de manifestación aguda, las agudezas de acción, conceptuadas genéricamente como derivados ocasionales de la agudeza del concepto: «No siempre se queda la sutileza en el concepto, comunicase a las acciones; son muchos y primorosos sus asuntos". Ibíd. Vol. II, p. 141. 
incluso por el examen tradicional de la doctrina pregracianesca, que por concepto se entiende el producto ingenioso relacionado con lo intelectual y que produce expresiones agudas, añadiendo a la gravedad y profundidad de las sentencias un claro rasgo de sorpresa ingeniosa. Sin embargo, cumpliendo básicamente todas estas condiciones, se agrupaban a veces los más heterogéneos tipos de juegos intelectuales y verbales. Predominaban ya desde Alonso de Ledesma el simil bizarro, la comparación violenta, la alegoría hiperbólica o la metáfora catacrética, como tipos conceptuosos por excelencia.

Gracián caracteriza definitivamente este mecanismo del salto entre realidades discontinuas, y en la vida común habitualmente disociadas, como definición del concepto:

«Consiste, pues, este artificio conceptuoso, en una primorosa concordancia, en una armónica correlación entre dos o tres cognoscibles extremos, expresada por un acto del entendimiento... $-\mathrm{y}$ explícitamente añade-. De suerte que se puede definir el concepto: Es un acto del entendimiento, que exprime la correspondencia que se halla entre los objectos. La misma consonancia o correlación artificiosa exprimida, es la sutileza objetiva" ${ }^{37}$.

A este artificio de agudo contraste, ya sea por semejanza ya por desigualdad bien ponderada, refiere el jesuita aragonés los tipos más sistemática y claramente conceptuosos de toda su Agudeza, siendo esta misma consideración común a todos sus criticos recientes ${ }^{3 *}$.

37 Ibid. Vol. I, p. 55 .

38 Cfr. Fernando Lázaro Carreter, Sobre la dificultad conceptista, en Estilo barroco y personalidad creadora, Salamanca, Anaya, 1966, pp. 11-59, ha dedicado una parte de este estudio al examen, desde las categorias de la Retórica tradicional, de la descomposición y clasificación de algunas de las modalidades fundamentales en que se expresa la integración conceptuosa de parcelas distantes de la realidad, en virtud de la cual «la visión directa ha quedado sustituida por una visión refleja», p. 15. A metaforismo violento, catacrético, reduce paralelamente A. A. Parker el tipo fundamental de conceptos quevedescos. A. A. Parker, La agudeza en algunos sonetos de Quevedo. Contribución al estudio del conceptismo, en Estudios dedicados a Menéndez Pidal, Madrid, 1952, Vol. III, pp. 345-360. Coinciden en lo básico con las descripciones más clásicas como la de E. Sarmiento, en su Gracian's "Agudeza y Arte de ingenio" en "The Modern Language Review", 1932, XXVII, pp. 280-292 y 420-429, con el posterior análisis de T. E. May, especialmente en An interpretation of Gracian's Agudeza y Arte de ingenio, en aHispanic Review", 1948, XVI, pp. 257-300, cuyo contenido sobre el concepto resumirá en un trabajo posterior en los siguientes términos: «... a visible manifold of images with to some extent disparate relationship, established simultaneously between them, by the use of tropes of other words capable of bearing some kind on double meaning". Cf. An interpretation of Gracian's «Agudeza...», cit., p. 15. 
El contraste del mecanismo conceptuoso aparece continuado en la opinión de Gracián, quien, una vez terminada su fundamental clasificación de los tipos de agudeza, se cree en la obligación de sustituirla por razones de mayor propiedad por una clasificación general de los conceptos basada en su expresión de semejanzas y desemejanzas:

«Más propriamente se dividiera en agudeza de correspondencia y conformidad entre los extremos objectivos del concepto, que son los correlatos, que une para la artificiosa sutileza... La otra es agudeza de contrariedad o discordancia entre los mismos extremos del conceptos ${ }^{39}$.

Por muy entusiasta que se muestre Gracián al dar la preeminencia y quintaesencia de la conceptuosidad a este esquema de metaformismo violento, catacrético, no cabe duda de que la tradición conceptista señalaba igualmente como conceptos muchos otros rasgos de ingenio no necesariamente incluidos en el esquema de violentos contrastes. En el fondo de muchos de ellos generalizados y catalogados muy claramente - la hipérbole, el equívoco, etcétera... - existía siempre la alusión latente o indirecta al contraste de un elemento marcado, de una realidad positiva, expresada y aludida ${ }^{40}$. En el caso de otros rasgos, como las simples salidas ingeniosas, los sencillos «desempeños» y "prontitudes", etc., donde no se ofrecía ya ninguna clase de paralelismo con las tácticas contrastivas, sabemos que se consideraban tradicionalmente como ingeniosos, designándolos en muchas ocasiones como conceptuosos, e incluso como puros conceptos.

Gracián no rompe tampoco en este punto con la tradición: a pesar de que su definición general de concepto en su inventario de agudezas

39 Cfr. Agudeza... ed. cit., Vol. 1, pp. 59-60.

40 Fernando Lázaro Carreter, glosando la conceptuosidad de recursos no metafóricos reconocidos en general y por Gracián como estrictos conceptos, afirma: “Ante estas afirmaciones no cabe duda de que la agudeza verbal es una táctica legítima para producir el concepto. Puede el entendimiento acudir directamente a los objetos, según ya vimos, para establecer relaciones, pero pueden también detenerse en las voces que los designan, por donde vendrá a producirse la mezcla y comunicación deseados». Cfr. Sobre la dificultad conceptista, cit, pp. 28-29. De modo similar T. E. May alude, como nosotros aquí, a la naturaleza final de contraste conceptuoso que existe bajo la inmensa mayoría de los recursos al verse tocados por la artificiosa agudeza: «The conceit of proportion is meant at once as a distinct type of conceit and as a revelation of the essential art of wit. In one way or another it can be said to contain all the rest». Cfr. T. E. May, Gracian's Idea of the "conceptos, cit., p. 27. 
dé cabida a un gran número de manifestaciones del ingenio de indole no metafísica. En tales casos, especialmente patentes cuando se ocupa de la ingeniosidad no contrastiva en la segunda parte de la Agudeza, la denominación concepto cede terreno a otras más genéricas y menos comprometedoras, tales como ingeniosidades, sales, y muy en especial agudezas. A pesar de todo Gracián se esfuerza en destacar, siempre que puede, cualquier parentesco o dependencia entre tales agudezas y el género del concepto de proporción. Tal es el caso, por ejemplo, de la «agudeza crítica y maliciosa», que entre sus muchas especies no tiene por qué adoptar forzosamente la disposición contrastada, como se deduce de la propia definición de Gracián ${ }^{4}$. Sin embargo recomendará vivamente, para destacar la condición de concepto en los que él llama con insistencia "pensamientos", realizar la glosa sobre elementos proporcionables positiva o negativamente. Pero véase que Gracián lo considera ya verdadero concepto antes de que intervenga tal tipo de ponderación:

«Llega al mayor primor de su sutileza este concepto, cuando cae sobre reparo; pondérase la desproporción del objecto, y luego se le da salida por una maliciosa crisi».

Estas observaciones las repetirá continuamente a lo largo de todo el Discurso que estamos comentando. Si antes insistió sobre la ponderación por desproporción, más adelante lo hará por la vía inversa: «Válese el ingenio para esta malicia crítica de la correspondencia, entre los términos della, busca siempre alguna correlación proporcional, para que sea con fundamento el concepto". Aun aludirá más adelante a la naturaleza ambigua de cualquier otra “circunstancia especial», como medio para reforzar el concepto ${ }^{42}$.

En otras ocasiones la opinión de prioridad en que Gracián tiene el concepto de proporción ${ }^{43}$ se manifiesta en la injustificada aparición sin

41 «Consiste su artificio en glosar, interpretando, adivinando, torciendo, y tal vez inventándose la intención, la causa, el motivo del que obra, ya a la malicia, que es lo ordinario, ya el encomion. Ibíd. Vol. I., pp. 255.

42 Cfr. Agudeza, ed. cit. Discurso XXVI, los textos antes mencionados en Vol. I, pp. 259 y 260, una nueva repetición es: «Siempre que da pie al concepto alguna circunstancia especial, es más sutil por lo fundamental y porque se hace ingeniosamente el reparo sobre la especialidad della». Ibíd. Vol, I, p. 262.

43 Esta evidencia que, como vemos, no lleva a Gracián a romper con la tradicional y ambigua amplitud de extensión de la noción concepto, ha sido puesta de manifiesto suficientemente por la crítica como resultado de una larga tradición conceptista muy visible 
más de la designación concepto, aunque sea imposible por la naturaleza del artificio ceder en su definición al contraste proporcional, ni siquiera mediante «encarecimiento». Por ejemplo en el caso de los «enigmas", de los que no ha hallado la forma de inscribirlos en el esquema clásico del concepto, nos dice sin más justificación: «Hay libros enteros destos conceptos enigmáticos, algunos muy fríos, otros muy ingeniosos» ${ }^{44}$.

No es necesario esforzarse en seleccionar ejemplos aislados como los anteriores, que permitan conjeturar más o menos verosimilmente la opinión de Gracián sobre estos problemas. Él mismo, como en tantos otros casos, insistió suficientemente sobre ello en su Agudeza con testimonios explícitos; es el caso por ejemplo del Discurso XLIX, donde se desarrolla «la agudeza por alusión», que consiste en invocar sólo una frase, dicho u ocasión históricos, sugeridos a un propósito cualquiera con el que no tiene por qué guardar proporción positiva ni negativa. Ello daba pie más que suficiente para que la previsión de Gracián se desencadene, como de hecho ocurre al final del Discurso, haciéndose eco de los posibles reparos:

«Algunos han querido esforzar que la alusión en sí, no es concepto, si no incluye alguna otra especie de agudeza, como es la correspondencia de los correlatos, contraposición, semejanza o paridad, y así otras, pero no hay duda, si no que ella sola hace concepto de por sí, aunque no se junte con otro... Alabándole a Nerón -pone como ejemplo- el plato de los hongos, muy validos entonces en Roma, dijo él en confirmación: Al fin son comida de Dioses; aludió al hongo envenenado con que mataron al emperador Claudio, su antecesor, y después le repusieron entre los dioses, según sus ciegos y vanos ritos". Confiesa Gracián que «no tiene este pensamiento otra agudeza más que la alusión a la historia», pero se esfuerza inmediatamente en buscar la base de comparación que en el fondo pudiera sustentar el recurso:

«Bien es verdad, que la relación a la historia a que se alude es

en Gracián. Trató de todo ello Edward Sarmiento, On two Criticisms..., cit.: «The beauty of the conceit resides primarily in the relationship established between the elements of the subject-matter, and secondarily, an aspect neglected by Gracian, though appreciated by him, as we may see from the many examples of those he gives which are not true or perfect conceits in the strangeness of the elements, or of the fact of their juxtaposition, or in its violent or fantastic method", p. 26.

44 Cfr. Agudeza, ed. cit., Vol. II, p. 108. 
correspondencia que sirve para la acomodación, pero esta correspondencia es el medio común, es como el instrumento general para todas las especies de agudeza que se forman por el careo y correlación».

Pese a lo cual, el carácter lejano de muchas alusiones obliga a Gracián a renunciar a su empresa y declarar que, incluso siendo conceptos, resulta en muchos casos imposible determinar la correlación ${ }^{45}$.

Agudeza como término del proceso artificioso, y concepto: he aquí las dos expresiones con que Gracián denomina las consecuencias de la agudeza, procedimiento hijo de la capacidad del ingenio. Una auténtica familia completa. Concepto, realidad más concreta y restringida que agudeza, es el tipo más artificioso y donde destaca la más afilada agudeza. De ahi viene el esfuerzo de Gracián por aplicar los principios de la lógica conceptuosa y el nombre de concepto a todo tipo de agudeza. Con ello obedecía a la moda más común y consolidada en España desde hacía ya más de cincuenta años en la conversación erudita, en la crítica y en la teoría sistemática de la literatura ${ }^{46}$.

Considero ya con lo que acabo de ofrecer definido lo que entendía Gracián por concepto dentro del extenso género de procedimientos en

45 Ibíd., Vol. II, p. 158. Muestra Gracián además un claro ejemplo de alusión sin proporción o correlación: "Con todo eso se hallan algunas alusiones que aun ésa no la incluyen, como ésta, no menos ingeniosa y picante que las pasadas. Entrando el Marrufino a besar la mano a Luis Undécimo, de vuelta de saquear a Cambray; traía un riquísimo collar de oro con mucha pedreria; reparando en él, los demás Monsiures, y alabándoselo, alargó uno dellos la mano para quererlo tocar. Al punto el rey, con mucha sal, que debiera con más celo: "Ta, dijo, no lo toquéis, que es cosa sagrada", aludiendo a lo que se murmuraba, que lo había hecho de las custodias y relicarios de las iglesias que había despojado. Así que consiste el artificio de esta y otras semejanzas, en un apuntar sin explicarse del todo, que basta a ocasionar el reparo, y despertar la curiosidad en el que no lo entiende y el gusto en el que lo entiende".

46 Véase de acuerdo con nuestra opinión, la agrupación proporcional de concepto, agudeza e ingenio, en una misma comunidad operativo-ingeniosa, que hace T. E. May: «lt is rather the field in which he lost understands art in general, in which there comes to its best expression something that all art seeks to express. It is quite reasonable for him to use the term agudeza in the second part of the work to embrace, in a large sense, all imaginative literature. The ingenio is for him what the poetic imagination is for the romantic; the concepto is its shortest flight». Cfr. Gracian's /dea of "concepto», cit., p. 18.

Aproximaciones analiticas a estas nociones fundamentales en la estética literaria de Gracián son: P. González Casanova, Verdad y agudeza en Gracián, en "Cuadernos Americanos", LXX, 1953, n. ${ }^{\circ} 4$, pp. 143-160, y F. Maldonado de Guevara, Del «ingenium" de Cervantes al del Gracián, en «Anales Cervantinos", VI, 1957, pp. 97-111. 
el que se mueve la agudeza -genéricamente denominados con frecuencia conceptos-. Paso a examinar ahora el mantenimiento en la Agudeza de Gracián de otras notas del concepto, tal como eran concebidas tradicionalmente. Me detendré para ello en la peculiaridad seguramente más sobresaliente del concepto tradicional, a la que en un grado $\mathrm{u}$ otro han de corresponder las demás: su fragmentariedad. El concepto se identificaba con frecuencia con los dichos breves, las sentencias, las agudezas fragmentarias..., hasta el punto de que el conjunto de una obra conceptista - sermón, poema, o libro doctrinal- era entendido como una especie de mosaico de unidades conceptuosas con los más variados orígenes y cauces de la ingeniosidad sentenciosa. El elemento unitivo de aquel conjunto de ingeniosidades era con más frecuencia fruto del placer del maravillado auditorio, que logro del ingenio del predicador o poeta. Éstos confiaban deslumbrar con los prodigiosos efectos de eco de cada uno de sus efectismos conceptuosos, en la seguridad de que la respuesta emocional de cada uno de ellos suplía con ventaja la sintaxis de una trama congruente.

Con esta nueva moda de géneros y estilos se produce una inversión de los principios de la Poética clásica, que desde Aristóteles censuraba el predominio de digresiones episódicas, o de los rasgos de sentenciosidad doctrinal.

También Horacio insistía en esa cuestión con ejemplos que resumen su crítica a todo detallismo que desenfoque la visión estructural de conjunto. Unidad y armonía en la unidad expresados en Aristóteles y Horacio con símiles de prestigio duradero, como los del cuerpo de animal perfecto en la Poética del primero, y el del monstruo, el artífice de estatuas, o el pintor de detalles del segundo.

La nueva situación barroca, el desplazamiento anecdótico de la mirada del artista y la visión del espectador, era ya un hecho en el siglo XVII después múltiplemente atribuido ${ }^{47}$. Gracián se hace eco elocuentemente de ello en toda la segunda parte de su obra dedicada a la Agudeza compuesta; entendiendo como tal desde un compuesto de conceptos en una composición lírica extensa hasta la estructura general de toda una epopeya, fruto en definitiva de la agudeza.

Pero lo que parece ir encaminándose en Gracián incluso hacia un

47 Recordemos este rasgo, aplicado por Ortega y Gasset a la actitud del Barroco a propósito de la pintura de Velázquez, en Sobre el punto de vista en las artes, en Obras Completas. Madrid, Ed. Rev. de Occidente 1966, 6. ${ }^{a}$ ed., Vol. IV, pp. 443-459; y después también por Arnold Hauser como uno de los síntomas principales del gusto manierista. A. Hauser, Historia social de la Literatura y el Arte, Madrid, Guadarrama, 1967 (4. ${ }^{a} \mathrm{ed}$.). 
tratado de géneros literarios, más o menos vinculado con la virtud de la agudeza, se desata rápidamente en una serie de afirmaciones generales apresuradas y en desorden, para recaer al fin en su verdadero objeto de interés: la agudeza fragmentaria y su capacidad de integrarse en unidades complejas, que no atentan contra la autonomía y fragmentariedad de sus componentes. Léase la conocida formulación gracianesca de ambos tipos con la que se inicia el Tratado Segundo de la obra:

«¿Cuál sea más perfecto empleo del ingenio, la agudeza libre o la ajustada a un discurso? La suelta es aquélla en la cual, aunque se levantan tres y cuatro y muchos asuntos de un sujeto, ya en encomio, ya en ponderación, pero no se unen unos con otros, sino que libremente se levantan y sin correlación se discurren. Sea ejemplo la ingeniosa panegiri del segundo Plinio a Trajano, que es un agregado de asuntos y de agudezas, sin unirse entre sí, sino en el material sujeto de la alabanza; lo mismo practican en lo sacro, el cultamente elocuente Hortensio Paravisino"..., y tras la relación de tal género de predicadores, añade: «La encadenada en una traza, es aquélla en que los asuntos, así de la panegiri, como de la ponderación suasoria, se unen entre sí como parte, para componer un todo artificioso mental ${ }^{48}$.

Siguiendo el viejo método escolástico, en correspondencia a los hábitos de su propio carácter, Gracián elogia ahora los méritos de la agudeza compuesta, como en el resto del libro lo había hecho de la simple:

"Siempre un todo - resume el argumento de «los contrarios»-, así en la composición física, como en la artificial, es lo más noble, el último objecto y el fin adecuado de las artes; y si bien su perfección resulta de la de las partes, pero añade él la mayor de la primorosa unión... No merece llamarse gusto el que deja la agudeza aliñada por la descompuesta y desatada, cuando su mismo nombre condena en la una su desaliño y aprueba en la otra su artificioso aseo" ${ }^{49}$. 
Evoca como refuerzo de tales razones la conducta de «la ingeniosa Grecia» y de «la docta Italia»:

«Esta, pues, gran madre del saber, emporio universal de las artes y ciencias, estimó siempre por de más arte y primor la agudeza compuesta, y la platican hoy sus más floridos ingenios en tantos, tan elocuentes y sazonados discursos».

A pesar de todo, e incluso del esfuerzo con que ha defendido este parecer, Gracián no nos oculta su preferencia y gusto personal. Es ya clave la enigmática conclusión con que da salida a las razones anteriores:

«Altercada deste modo por una y por otra parte la cuestión a todo discurrir, al fin cada uno abunda en su dictamen. Pero mucho puede el uso, y más la agradable, plausible y hermosa variedad".

Dejando a un lado si la ambigua designación de variedad alude claramente a la preferencia gracianesca por el variar y sucederse en la unidad monótona del discurso de estas flores y sales de varia índole que eran los conceptos, lo que sí queda claramente demostrado es que la "variedad" de las razones garantizadas por el uso compara en plano de igualdad el «parecer español» al de la «ingeniosa Grecia» y al de la "culta Italia». Por poco que se sepa acerca de la presión sobre el pensamiento renacentista en general de la autoridad griega, y del complejo de inferioridad respecto de lo italiano en que vivían nuestros ingenios del siglo XVI, podrá valorarse adecuadamente con este testimonio del cauto Gracián el grado de confianza que el dominio del arte conceptista había infundido en los españoles. En nombre de ella el jesuita aragonés, entusiasta de la renovación artística que aportaba el conceptismo, se atreve a parangonar las razones de todos como fundadas en criterios de autoridad equivalentes.

Gracıán, que como indicábamos al comıenzo, no había dudado en atribuir "la libertad de ingenio" —ahora sabemos que no era otra cosa que la preferencia por las agudezas sueltas- como constante multisecular española, vincula así su propio parecer a la conciencia nacional triunfante. Esto es lo que realmente nos interesa en nuestras actuales consideraciones. Por encima de la opinión de gusto, siempre relativa como agudamente advierte Gracián, el hecho histórico que afirma la Agudeza es el asentamiento en la conciencia española de la esperanza de un pueblo en un arte y en una cultura, cuyas características sentía como la más natural expresión de sus propias esencias. De su 
dignidad se esperaba poder comparar los méritos artísticos de España con los de Grecia o Italia ${ }^{50}$.

La primera consecuencia en el hecho del convencimiento general dominante en España sobre el carácter fragmentario del concepto es su contraposición a “asunto" o «argumento" de una obra. Ya se sabe cómo por lo general en la preceptiva de la poesia lirica, procedente de las ideas de Dante y Petrarca sobre sonetos, canciones, baladas y madrigales, para defender la naturaleza imitativa -y por tanto poética en una rigurosa aplicación de las ideas aristotélicas- de tales composiciones, ya que no podía decirse que en su fábula se imitaran acciones, se dijo que imitaban pensamientos. De aquí nació en su primera acepción romance el concepto-fábula, o más propiamente el conceptodix $v_{0} \alpha$, en obras artísticas en las que la estructura general de pensa-

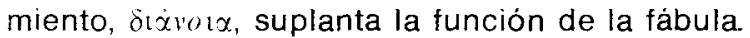

Sin embargo a lo largo de la evolución de las ideas sobre el concepto la solución del Dante, muy admitida en Italia, fue menos tenida en cuenta en España. Solamente en Poéticas cultas e italianizantes como la de Francisco de Cascales. Por el contrario, ya desde las primeras apariciones teóricas españolas de concepto, que pueden documentarse hacia la mitad del siglo XVI, aparece éste caracterizado como expresión

50 Gracián de modo expreso en este punto —puede verse con atención la línea de sus argumentos en el desarrolio completo de este Discurso LI- y por la actitud general que testimonia en la obra compleia, no oculta sus preferencias respecto a esta disyuntiva. Mientras desmenuza atentamente las más insignificantes variedades de la agudeza individual, pasa como sobre ascuas por las muestras épicas, alegorias, diálogos, etc., de la agudeza compuesta Evitando conectar el tratamiento de estas agudezas compuestas con la extensísima tradición poética de la Epopeya, la Novela o el Teatro. Eñ él no actuaba la conciencia de la unidad estructural de la obra literaria. Para la óptica barroquista de Gracián la única reflexión válida sobre tales estructuras parece consistir sólo en determinar lo que corresponde al esfuerzo ingenioso en la operación de elaborar sus producciones. Gracián tratando de la agudeza compuesta habia reservado para las obras de los géneros ciásicos una atención incompleta e improporcional, como muestra ya su propósito de trabajo: "La agudeza compuesta es de dos maneras y otros dos son los géneros de compuestos. EI primero es el que se compone de conceptos incomplejos, como de tres o cuatro proporciones, de tres o cuatro reparos, paridades, etc., unidos entre si y que hagan juego de correspondencia. El segundo, es un compuesto por ficción como lo son las épicas, alegorías continuadas, diálogos, etc...». La simple alusión de las "épicas» entre elementos tan raramente homogéneos en la Teoria Literaria, sería ya suficiente prueba de to que estamos diciendo; además, aunque Gracián se proponga ir explicando ambos géneros por su orden en los discursos siguientes, la verdad es que en ellos desaparece todo esquema proporcional con las jerarquias de la Poética tradicional. Téngase presentes especialmente los discursos LIV, LV y LV!. 
breve, especial testimonio de ingenio, con capacidad autónoma de producir por sí mismo la respuesta de sorprendente admiración en el auditorio. Por tanto la finalidad del concepto no es la de desplazar de ningún tipo de composiciones al "asunto" o "argumento», sino la de introducirse en él, incrustándose desde luego en situación preferente como piedra preciosa en engarce de latón.

En Gracián triunfa, como vemos, el estado de opinión más genuinamente español.

Son muchas las ocasiones en las que sujeto, objeto, argumento o asunto, aparecen citados junto a concepto en un mismo contexto como realidades diferentes siempre en su conjunto. $Y$ además que tales citas responden casi siempre a composiciones líricas de escasa extensión. Así: «... como se ve en este laureado soneto, de Bartolomé Leonardo, por el asunto, que fue a San Laurencio, y por el concepto, que fue grande». Aunque resulta muy ilustrativo hacer observar en relación con asunto la alternancia de concepto como asunto lírico, frente a asunto como argumento oratorio: «Pide muy diferentes pensamientos, y aun palabras, una carta familiar que una oración; ni merece ser asunto principal de un sermón el concepto que es brillante para un soneto" 51 . Valga esta fluctuación como nuevo testimonio de que el desgaste semántico de los tecnicismos literarios en el Siglo de Oro llegó incluso a los entendimientos más rigurosos y analíticos como el de Gracián, los cuales se veían obligados a deteriorar clasificaciones muy fundadas mediante el indiscutible enmascaramiento que ofrecen estas forzadas formas de sinonimia. No obstante la actitud general que indicábamos, de distinguirse en la Agudeza entre el argumento y sus sinónimos y el concepto se salva en la mayoría de los ejemplos, como en el siguiente:

«Fue sublime pensamiento este del padre Francisco Remondo, jesuita, por el objecto que fue a la Encarnación del Divino Verbo, y por el concepto, que fue sutil» 52 .

Si estas declaraciones no bastan para ilustrar la opinión sobre la fragmentariedad del concepto que tiene Gracián —a la vez que su condición de ingrediente o agregado, lo que exige un cemento imaginativo en torno como condición imprescindible para integrarse en es-

51 Ambos textos en ibid. Vol. I, p. 74 y II, p. 231 respectivamente.

52 Ibíd., Vol. l, 261. "Lo más arduo y primoroso destos compuestos de ingenio falta por comprender, que es la unión entre los asuntos y conceptos parciales», Vol. II, p. 183, etc... 
tructuras más extensas de discurso-, sirva entonces de prueba indiscutible el gran número de ocasiones en las cuales el autor deja traslucir su opinión al hablar de la composición conceptuosa interna de sonetos, epigramas, madrigales $\mathrm{u}$ otras clases de poemas. $Y$ sobre todo los que Gracián llama «los compuestos de agudeza». Por ejemplo, del soneto de Garcilaso ; Oh dulces prendas por mi mal halladas!, leemos: "Resplandece esta conformidad con el entendimiento en este compuesto de conceptos, soneto del celebrado Garcilaso". E igual que en el soneto, lo demuestra en el madrigal; como en la siguiente alusión, en la que ejemplifica además el procedimiento de asociación conceptuosa para alcanzar la estructura de la composición del soneto:

«Hasta un epigrama es adecuadamente perfecto, cuando se vienen a unir los conceptos y hacer un cuerpo atado con alguna traza, como se ve en aquel gran soneto de don Luis de Góngora al marqués de Castel-Rodrigo, que comienza: Árbol de cuyos ramos fortunados, y este otro, de todas maneras relevante, por la pluralidad de conceptos y singularidad de cada uno, pero mucho más por la trabazón y composición que todos ellos hacen» 53 .

En el caso de composiciones de estructura métrica abierta y por tanto indeterminadas en el número de sus versos, como el romance, Gracián reconoce la pluralidad conceptuosa. A tal efecto nos ofrece algún ejemplo, en el que por cierto se señala cómo una breve quintiIla, que pudiera suponerse la mínima expresión para que aparezca un solo concepto en opinión de Gracián, no se considera así. Se habla a propósito de ella de "un concepto más que mediano»; es claro que se sobreentiende "como mínimo», y que se fija en esa cuantía precisa el límite mínimo de los conceptos mayores, no de los demás:

«El romance quiere -éste es el ejemplo- conceptos galantes más que profundos; figuras rectóricas, más de la palabra que de la sentencia; estilo florido y bizarro. Las quintillas piden cada una un concepto más que mediano; las sentencias las realzan muchom ${ }^{54}$.

Porque no sólo en la quintilla, sino incluso en menores extensiones

53 Ibíd., Vol. 1, 52 y II, 170-171, respectivamente. La asimilación de soneto a epigrama a que aludimos, puede verse expresamente en Vol. II. p. 232.

54 Ibid., Vol. II, p. 232. 
de discurso considera posible Gracián la inclusión de varios conceptos. En el breve término de dos tercetos, extensión algo superior a la quintiIla, sería posible ${ }^{55}$, e incluso en dos versos ${ }^{56}$; llegando hasta a la evidente exageración retórica de afirmar en tono demasiado general que en las sílabas y los acentos de una palabra se puede hallar conglomerada variedad de conceptos.

«Es como hidra bocal - se refiere a la agudeza nominal- una dicción, pues a más de su propia y directa significación, si la cortan o la transtruecan, de cada silaba renace una sutileza ingeniosa y de cada acento un concepto" ${ }^{57}$.

Esta propiedad breve, móvil y acomodaticia del concepto que condiciona, como estamos viendo, el juicio sobre él que tiene Gracián, quien reflejaba la opinión general sentida en el país como herencia de una tradición precedente, concuerda también con el parecer de la mayoría sobre su finalidad, utilidad y empleo.

De esta forma la Agudeza de Gracián nos ofrece en los Discursos LIIl y LIV uno de los más ricos documentos que nos ha legado el Siglo de Oro, sobre muy curiosas circunstancias de la vida y la conciencia artística de la época. Es una aguda exposición sobre los motivos de la extendida moda de sofocar con «erudición" ingenuamente manejada el ordenado fluir de un razonamiento sensato, de un inspirado argumento de ficción. Incluso la misma forma en que Gracián lo expone, ofrece por sí misma un verdadero testimonio del ideal artístico y vital que preconiza.

Reproducimos aquí por extenso el conocido fragmento sobre la docta erudición:

«Denomínase, según algunos, de la oposición contra la rudeza y ignorancia; consiste en una universal noticia de dichos y de hechos, para ilustrar con ellos la materia de que se discurre, la doctrina que se declara. Tiene la memoria una como despensa

55 Ibíd., Vol. I, p. 174

56 Ibíd., Vol. I, p. 61.

57 Ibíd., II, p. 37. Ni que decir tiene que las obras extensas, dramáticas, épicas, etc..., admiten y precisan de gran cantidad de conceptos; por obvio no insiste en ello Gracián sistemáticamente, pero sí lo hace alguna vez de modo ocasional, como al hablar de la comedia que Gracián llama poema, de Antonio de Mendoza, Querer por sólo querer. Ibid., Vol. I, p. 56. 
llena de este erudito pasto para sustentar el ánimo y de qué enriquecer y fecundar los convites, que suele hacer a los entendimientos. Es un magacén rebutido, un vestuario curioso, un guardajoyas de la sabiduria. Sin la erudición, no tienen gusto ni substancia los discursos, ni las conversaciones ni los libros... Sin este sainete son secos y desabridos los discursos, por ingeniosos y picantes que sean, luego enfadan y los pierde la atención del que oye, o los arrima la del que lee» ${ }^{58}$.

Con semejante aliño, viene a decir Gracián, no hay carne mala; lo que significaba el eclipsarse en la estética barroca española de una de las instituciones fundamentales de la teoría poética tradicional: la doctrina de los géneros, siempre en clara conexión con concepciones más o menos estructurales de la jerarquía social. En contraposición a los tradicionales géneros de la amena y deleitosa ficción argumental, activadores del deleite y de la moralización artística, sucede ahora el fenómeno de que los más aburridos géneros y materias - los discursos históricos, los sermones de exequias, los tratados de arte militar, etc... - pueden adquirir mediante el añadido de un caudal de conceptos, nunca mal acogidos por un público bien. "mentalizado»"59, una lograda amenidad e interés populares que los lleve a rivalizar en el favor de masas con los productos artísticos tradicionalmente más reputados de deleitosos y populares, como eran dramas, comedias, epopeyas, novelas, etc.:

"Acontece no ser el cuerpo todo de la obra tan perfecto como otros, pero la eminencia de la erudición le hace agradable en gran manera y que sea más versado... Las comedias, épicas y otras ficciones, con sus enredados empeños, deleitan. Los discursos, si no se favorecen de la erudición, son secos, estériles y empalagan» ${ }^{60}$.

Lo que parece claro de todo ello, en compensación, es que estos

58 ibíd., II, pp. 217-218.

59 La representatividad jesuítica de la estética de Gracián ha sido muy discutida. Destacamos: Miguel Batllori, La barroquización de la Ratio Studiorum en la mente $y$ en las obras de Gracián, en Studi sulla chiesa antica e sull'Umanesimo, Roma, 1954, pp. 157-162; del mismo autor, La Agudeza de Gracián y la retórica jesuitica, en Actas del 1. "r Congreso Int. de Hispanistas, 1964, pp. 57-69.

60 Cfr. Agudeza..., edic. cit., Vol. II, p. 219. 
géneros tan poco amenos, una vez transformados, se habian convertido en verdaderas caricaturas ${ }^{61}$.

El rasgo de brevedad artificiosa que parece caracterizar esencialmente el concepto según lo concibió Gracián, nos pone a las puertas de otra importante cuestión: los límites entre pensamiento y expresión a propósito de la doctrina del concepto. En efecto, frecuentemente resulta imposible diferenciar en los textos de los escritores de los siglos XVI y XVII si lo que designan como concepto es un hecho de expresión antes que de estricto pensamiento. En ellos aparece muy estrechamente vinculada la esencia del pensamiento-concepto a la concreción de la forma breve, aguda y artificiosa con que solía aparecer expuesto.

La actitud de Gracián es de las más conscientemente explicitas. Ya conocemos el cuidado con que el jesuita aragonés establecía la distinción entre figura retórica y concepto: entiende la primera como el soporte material donde se deposita el acto del entendimiento que ilustra misteriosas proporciones en la realidad. Hemos señalado también la condición absolutamente intelectual del "careo" en que se funda la agudeza conceptuosa. $Y$ podemos decir que, en la inmensa mayoria de los centenares de alusiones a concepto, el límite entre la naturaleza intelectual de éste y su expresión concreta está muy bien representado, como en el elogio al "gran Ambrosio, cuyo nombre bautizó misterioso sus escritos, siempre conceptuoso sobre elocuente, pero en el discurso de Santa Inés, apasionado" ${ }^{62}$. El concepto es para él algo necesitado de expresión "declarable", sin capacidad de hacerse sensible si no es a través de las palabras. Por ello reaparecen en Gracián las quejas corrientes sobre los excesos a que conduce la polaridad entre ambos componentes, como en las siguientes líneas a propósito de un soneto del «pronto» Juan Rufo:

«Está tan lleno de conceptos, que él sólo contiene más que ciento de aquellos cuya felicidad para en follaje inútil de palabras, sin fruto de agudeza" ${ }^{63}$.

61 En este arte que proclama el predominio de la agudeza, del ingenioso concepto siempre a punto para ser aplicado, incluso son conceptos las prontitudes, es decir las respuestas o desempeños a condición de que sean breves, inmediatos e ingeniosos. Con gran frecuencia leemos el término prontitud en sustitución clara de concepto: «Excelente moralidad, y el ser a la ocasión, hace la prontitud más gustosa".

62 lbid., Vol. I, 75.

63 Ibid., vol. l, p. 174. 
No está libre Gracián de peligrosas oscilaciones de opinión en este asunto, ni tampoco de contextos en los que los términos tantas veces deslizados vuelven a presentarse confusos. Como, por ejemplo, el caso de los "conceptos por equívoco", donde confiesa Gracián la alta dosis de ingeniosidad que corresponde a la naturaleza expresiva de los mismos:

"Tienen esta infelicidad los conceptos por equivoco, que no se pueden pasar a otra lengua; porque como todo el artificio consiste en la palabra de dos significaciones, en la otra lengua ya es diferentes ${ }^{64}$.

En otros lugares esta correlación entre pensamiento y expresión deslizada hacia el segundo término se manifiesta todavía más clara con el empleo de la expresión dicho referida a productos conceptuosos. En la Italia de 1630 la sinonimia entre dicho y concepto debia de ser muy frecuente. Así aparecía en el título de la obra de Pellegrini. En España, aunque menos frecuente, no era tampoco insólita.

Gracián maneja dichas expresiones en acepción posiblemente similar y con evidente propósito de evitar repeticiones inelegantes. En el prólogo al lector:

«El predicador estimará el substancial conceto de Ambrosio; el humanista, el picante de Marcial. Aquí hallará el filósofo el prudente dicho de Séneca; el historiador, el malicioso de Tácito; el orador, el sutil de Plinio, y el poeta, el brillante de Ausonio" ${ }^{65}$.

El mismo título de la obra en su edición de 1648 es ya bien significativo, Agudeza y arte de ingenio. Donde se explican todos los modos, y diferencias de conceptos, con exemplares escogidos de todo lo más bien dicho, assi sacro, como humano. Al destacar el valor de lo «bien dicho" en los "ejemplares" con que se ilustran los conceptos, pone sobre el tapete el condicionamiento recíproco de ambos extremos.

Sin embargo cuando Gracián se detiene a definir el dicho, to hace de una forma restrictiva. Es éste un caso especial de la sentencia, aplicado exclusivamente a ocasiones de esfuerzo y decisión del ánimo:

«Asi como hay sentencias que exprimen la profundidad de la

64 Ibid., Vol. II, p. 55.

65 Ibíd., Vol. I, p. 45. 
mente, lo substancial de la inteligencia, así hay dichos magnánimos que declaran con excelencia la grandeza del valor, la valentia del corazón y la generosa majestad de un grande pecho. Osténtase en aquéllas la gran capacidad; en éstos el ánimo, dichos propios de héroes. Hay unos universales, hay otros singulares en todo, y cortados a la ocasión» 66 .

Esa restricción puede ser consecuencia de que el contenido del Discurso XXX se refiere precisamente a "los dichos heroicos", a los que se adapta perfectamente la definición anterior. No es por consiguiente una caracterización válida para la acepción amplia del dicho, más o menos asimilable a concepto con todas sus variedades, que empleaba Gracián en el Prólogo al lector. Sobre ello ni Séneca -fuera del posible matiz moral heroico que pueda adquirir su estoicismo al ser considerado tópicamente por un pensador hispano-, ni Tácito, Plinio o Ausonio podrían pasar estrictamente por ejemplares heroicos.

Atribuir el concepto a uno de los extremos de la dualidad pensamiento-expresión vinculaba muy generalmente a esa especulación, como se sabe, el problema de la delimitación concepto-sentencia. Era éste el término que, revestido de prestigio tradicional por ser un tecnicismo donde coincidian las traducciones de la $\delta i \dot{\alpha} v o t \alpha$ poética y de la

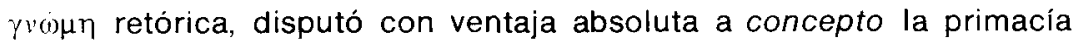
como denominación poética durante la primera mitad del siglo XVI y con estimación decreciente, aunque nunca anulada del todo, a partir de ese momento. En el empleo general de sentencia, fuera del caso de su traducción en tratados sistemáticos sobre la Poética de Aristóteles, predominó una indiscutible especialización expresiva, que la aproximaba más que a concepto hacia la vertiente de la formalización verbal.

En la Agudeza de Gracián encontramos, en éste como en tantos otros aspectos, la digna culminación de la teoría literaria de nuestro Siglo de Oro. De esta obra ha de salir completamente perfilado un significado de sentencia, que aunque difiere en algo del uso tradicional, nos ilustra por el contrario sobre la derrota del término ya en la época de Gracián en su competencia centenaria con concepto.

Cuantitativamente -en una simple impresión general- la mayor frecuencia en el empleo de concepto a lo largo de la Agudeza es muy considerable, y especialmente en el primer tratado resulta abrumadora. La sentencia aparece incluida en el Discurso primero de la obra en una 
de esas enumeraciones, en las que estamos acostumbrados a valorar escasamente tanto los rasgos sinonímicos como los opuestos, dada la enorme fluctuación semántica de los popularizados tecnicismos ${ }^{67}$. Pero la verdad es que no volvemos a encontrarla empleada hasta el discurso séptimo, y entonces como adjetivo, "razón... sentenciosa".

Súbitamente la descubrimos de nuevo cuatro veces en poco más de una página en el Discurso XII. Evidentemente era forzado a ello el autor en este uso por el título puesto al discurso "De las ponderaciones y argumentos por semejanza sentenciosa" ${ }^{68}$. Razón que no se da cuando nuevamente volvemos a encontrar sentencia repetidamente usada por tres veces en el breve espacio de una página ${ }^{64}$, y al observar que se trata de una cadencia que se repite con regularidad a lo largo de la Primera parte de la Agudeza, parece forzoso buscar alguna explicación. A nuestro modo de ver se trata simplemente de la necesidad de alternar las denominaciones por razones de agilidad estilistica para una misma noción, a la que es obligado aludir frecuentemente.

La sentencia, como deciamos, aumenta sus apariciones en la se. gunda mitad de la obra; precisamente al empezar a tratar las variedades de agudeza con modalidad no proporcional y por tanto menos genuinamente conceptuosa. Lo sentencioso sirve entonces a Gracián para designar el estilo grave, que incorpora severas máximas de carácter menos ingenioso quizá que el concepto, pero de mayor ponderación y efecto intelectual-moral. Sentencioso es, en tal sentido, incluso un término de cualidad que puede llegar a englobar al propio concepto haciéndole de predicado: «Tienen estos conceptos mucho de satíricos y algo de sentencioso" ${ }^{70}$.

Este carácter específico de la sentencia se pone de manifiesto cuando en el Discurso XIX se ocupa Gracián de la agudeza sentenciosa. Al definirla, cualquiera que sea su modalidad como concepto, entendemos en las razones que da Gracián que está aludiendo a la significación más amplia y casi más filosófica que poética de concepto. La condición que añade, para que pueda ser considerado con propiedad concepto ingenioso, su concreción singular, suponía abandonar la idea aristotélica de sentencia como «verdad universal»:

67 «Esta urgencia de lo conceptuoso, es igual a la prosa y al verso. ¿Qué fuera Augustino sin sus sutilezas y Ambrosio sin sus ponderaciones, Marcial sin sus sales y Horacio sin sus sentencias?». Ibid., I, p. 51.

68 ibid., Vol. I, pp. 138-139, cita tres veces sentencia y una sentencioso.

69 lbíd., Vol. I, pp. 160-161; esta vez el título del discurso no está relacionado con el tecnicismo. Gracián lo titula: "De la agudeza por paridad conceptuosa".

70 Ibid., Vol. II, p. 17. 
«Es esta la operación máxima del entendimiento, porque concurren en ella la viveza del ingenio y el acierto del juicio... $Y$ aunque cualquiera sentencia es concepto, porque esencialmente es acto del discurso una verdad sublime, recóndita y prudente, pero las que son propias de esta arte de agudeza, son aquellas que se sacan de la ocasión y les da pie alguna circunstancia especial, de modo que no son sentencias generales, sino muy especiales, glosando alguna rara contingencia por ellas» 71 .

En el tratamiento de la sentencia se confirma la condición general de gravedad y selección a que aludiamos. Se habla de unna prudente sentencia», de "la grave sentencia», y de cómo su aparición transforma cualquier pasaje jocoso: «Incluye tal vez en un equívoco una sentencia grave, que no siempre sirve a lo jocoso y burlesco". Las sentencias, nos dice en otro lugar, «realzan mucho» y tienen su lugar propio, como cualquier otra variedad de agudeza; es en las ocasiones más solemnes:

«Las agudezas sales sirven de recreación del ánimo, y aunque no admiran, deleitan; tan acertada fue una gracia en una carta como un misterio en un sermón, y tan agradable un donaire en una conversación como una sentencia en un consistorio; que si luce una estrella en lo más alto del cielo, también campea una flor en lo más humilde de un valle» ${ }^{72}$.

En resumen, en la Agudeza encontramos la decadencia en el empleo de sentencia frente al de concepto, sobre todo al especializar el término sentencia para expresar un pensamiento universal de forma escogida y solemne. Cuando la sentencia, procedimiento conceptuoso por ser producto del entendimiento como el concepto, se individualiza especializando y condensando su condición ingeniosa, se transforma progresivamente en concepto y va perdiendo, en el mismo grado, su carácter sentencioso.

Pensamiento-expresión, significante-significado, he aquí las polaridades entre las que, como hoy, se movía la Teoría Lingüística y Literaria de nuestro Siglo de Oro. Con el concepto nos encontramos ante uno de los ejemplos más claros de la dependencia de la Poética respecto a las teorias generales del lenguaje. Lo que sorprende al hombre de hoy es la sabia anticipación en cierto sector de tradición retórica,

71 Ibid., Vol. 11, p. 22.

72 Ibid., Vol. II, p. 233. 
donde Gracián se incluye con todo derecho, de concepciones lingüísticas de gran vigencia en la actualidad y alcanzadas en la moderna tradición científica sólo como el resultado de enormes esfuerzos.

Describir el concepto como un hecho de pura expresión es sólo decir una verdad incompleta, y no más falsa en el fondo que darlo como una realidad de contenido ${ }^{73}$. Hablar de "lenguaje de la maravilla" como hace el autor aludido en la nota anterior, Lange, es totalmente válido e indiscutible. Nosotros en todo caso debemos aclarar que aquí se está aludiendo a una concepción del lenguaje absolutamente actual, en la que la esquematización glosemática del signo y de los procesos de producción lingüística se ha enriquecido con las enseñanzas generativistas.

Ya Hjelmslev hizo ver cómo la concepción de un plano aislado, contenido o expresión, de una forma también aislada en uno de los planos, es sólo posible dentro de las especulaciones teóricas de la metalengua. En la realidad la formalización del contenido en unidades, cuyo proceso no llegó a considerar el lingüista danés, ocurre sólo porque dicho contenido está destinado a integrarse en un signo con una forma simultánea de la substancia de la expresión. Es decir, se trata de la acertada y definitiva formulación lingüística de nuestra intuición de hablantes, por la cual sabemos que las unidades de pensamiento y las formulaciones orales con que las representamos no son hechos sucesivos sino simultáneos en nuestro normal uso del idioma. La especulación generativa por su parte ha ilustrado el hecho de la simultaneidad en ese momento en que se sobreimponen las dos formas, sobre el esquema simplista de Hjelmslev. Hoy sabemos la complejidad de pasos sucesivos en que se realiza el proceso recíproco del encuentro de las unidades sémicas y las fonológicas.

Gracián estaba persuadido de los riesgos de una clasificación retórica demasiado simplista con tres momentos sucesivos: inventio, dispositio y elocutio, y no cae en el error en que habian sucumbido los esfuerzos de muchos de sus predecesores, al adscribir la competencia del concepto en exclusiva a uno de los dos extremos de la serie retórica, unas veces a la inventio y otras a la elocutio. Hacerlo habría significado ceder a la fácil generalización de una interpretación mal entendida en la propuesta clásica res-verba.

73 Como formulación expresiva se la califica con frecuencia; con el único inconveniente de que, si no se precisa más, sin decir falsedad no se dice su esencia. Véase por ejemplo el atento estudio sobre los conceptistas italianos de Klaus-Peter Lange, Theoretiker des literarischen Manierismus, Munich, 1968, p. 12. 
Gracián le concede al ingenio libre acción sobre los tres espacios retóricos tradicionales. De ahí resulta que la búsqueda ingeniosa de correspondencias intelectuales en la realidad es una modalidad de indagación lingüistica confiada a la agudeza. De la misma manera que construir un vínculo entre las realidades intelectivas y los significantes equivale a revisar los procesos expresivos del lenguaje y de su comportamiento frente a la realidad.

Si hubiera que reducir la competencia de la agudeza conceptuosa a una sola vertiente del triple esquema retórico, se diria que la actitud conceptista a través de Gracián escoge la dispositio para simbolizar mejor un proceso selectivo dentro de los procesos habituales del lenguaje. De ese modo se seleccionan tras su valoración por la agudeza los contenidos y expresiones no usuales e ingeniosos. Frente a la naturaleza pasiva de los contenidos retóricos designados por la inventio y la elocutio, le correspondía a la dispositio la función agente, selectiva, ordenadora de la relación entre las dos clases de «ingredientes". Igualmente móvil, inquisitivo y ponderador era el cometido asignado a la agudeza ingeniosa en su infinito sumergirse en los inventarios de cosas y palabras habituales, hasta lograr la asociación excepcional e insólita.

Pero podemos preguntarnos cómo podía participar Gracián de nuestra concepción actual del proceso lingüistico, desde la que se advierte esa polifacética incidencia en todos los planos del lenguaje, a que sin duda considero se extendía la luz del concepto. El metalenguaje actual no podía ser el mismo que el del jesuita aragonés; sin embargo la base de intuición era la misma. Un escritor e investigador tan experto en el lenguaje técnico filosófico de la edad gracianesca como el profesor Maldonado de Guevara nos ha ofrecido una satisfactoria explicación. Partiendo de la observación de Heidegger, de que en la terminología griega faltaba el término que tradujese el habla, Rede, como realidad diferente del discurso de pensamiento, Maldonado destaca la coincidencia en la designación griega de discurso de los dos componentes intelectivo y oral, en los que desde el punto de mira de las lenguas modernas se ha "equivocado" la unidad del proceso lingüístico:

"Y esto, que implica desde nuestro miradero, una aequivocatio, desde el miradero del lenguaje griego sobre los idiomas modernos entraña, a mi parecer, profunda y feliz univocación. $Y$ es que la diferencia entre Habla y Ratio es diferencia idiomática, y la univocación de ambas palabras se gesta y se franquea, no desde 
los desniveles de los idiomas, sino desde el pavimento firme del lenguaje" ${ }^{74}$.

Esta luz alcanza muchas resoluciones confusas en la Poética clásica y en las estimaciones literarias de nuestro Siglo de Oro. La salida a la problemática poética ofrecida por Aristóteles, acerca de la prioridad de la imitación —manipulación artística de la realidad- sobre el verso en la esencia de la poesía, encuentra su explicación adecuada. La transformación artística de la realidad no se realiza en literatura por el contenido, palabra y noción muy posteriores a Aristóteles; su actividad se debe a la cooperación de todos los recursos de la obra artística. Pero la fórmula más brillante de tal idea, que no salió demasiado bien parada de las especulaciones renacentistas sobre la dualidad resverba, la hemos hallado al fin en Gracián; expresada en los términos conceptistas que "corresponden a su especial concepción del arte, diferente de la de Aristóteles. Se trata de un fragmento, aparentemente secundario de la Agudeza, en el que la crítica no suele reparar:

«No es de esencia de la agudeza fingida el metro y composición poética, sino ornato que la prosa suele suplir con su aliñada cultura. No está la eminencia en la cantidad de sílabas, ni en la cadencia dellas, que eso es muy material, no pasa del oído; sí, en la sutileza del pensar, en la elegancia del decir, en el artificio del discurrir, en la profundidad del declarar" ${ }^{75}$.

«Sutileza, artificio, elegancia y profundidad» son los principios que diferencian el arte frente a cualquier representación no artística en el pensamiento de los artistas del conceptismo barroco. Se trata entonces de una valoración general del lenguaje como totalidad, ahondando en todos sus posibles planos. Al contrario de lo que han dicho las generalizaciones con que se ha caracterizado tradicionalmente el conceptismo frente al culteranismo. No existió la contraposición por tanto entre una desproporción de los hechos de contenido caracterizando al conceptismo, y de los recursos verbalistas que distingue a los llamados cultos o culteranos; acepción del término culto de la que Gracián no participa.

Conceptismo y culteranismo no eran dos bandos resultantes de la

74 Cfr. F. Maldonado de Guevara, El "cogito» de Baltasar Gracián, en «Revista de la Universidad de Madrid", VII, N. ${ }^{\circ} 27,1958$, pp. 271-329; p. 319.

75 Cfr. Agudeza, ed. cit., Vol. II, p. 198. 
disolución irreconciliable de los dos extremos en que se descompone la polaridad programática del arte clásico, res-verba. Los conceptistas españoles no se oponían a los cultos como res se opone a verba, en la actitud concreta de sus mejores representantes, Quevedo y Gracián. Ni siquiera ocurría asi como convicción general, según creo haber demostrado en la exposición precedente. Se trataba de un contraste aún más sutil e ilustrativo del profundo valor de la revolución artística barroca. Lo que en verdad se opone es, en el caso del conceptismo, un ideal clasicista integrado en el equilibrio de res-verba, de contenido y expresión indesglosables, explotando y sutilizando el lenguaje como globalidad significativa. Esto se conseguía afinando los efectos de agudeza para constituir los materiales de los dos planos, y especialmente mediante la disposición integradora de los mismos. De la parte cultista por el contrario se contrapuso la incidencia histórica de una eterna tentación en la evolución del clasicismo artístico: la desintegración anómala del lenguaje como realidad total, que considera llegado el momento para el lenguaje artístico autónomo. En el enfrentamiento de dos gustos opuestos al cumplirse el primer cuarto del siglo XVII en España no contrastan dos actitudes igualmente contradictorias respecto al ideal artístico-clasicista. Una de las dos, la conceptista, se proponía el fin más modesto de revitalizarlo, de mantenerlo activo, explotando sus mismos recursos bajo una nueva óptica. En el gusto triunfante con el Polifemo de Góngora late un propósito más innovador. Se trataba, por fin, de dar un importante ataque en la historia moderna del arte occidental a los principios del arte clásico. El genial y tenebroso Góngora decide la primera rebelión contra las exigencias de homogeneización lingüística de los recursos expresivos literarios. Mediante la aventura de una semántica artistico-sentimental transracionalista cuestiona, en la gracia esplendorosa de los significantes, los derechos de la lógica tradicional de la Poética clásica. En este sentido analizamos nosotros el antagonismo entre conceptistas y culteranos, simplemente como un caso de aparición histórica de la secular «querella de los antiguos y los modernos".

Esto explica que en oposición al enorme desarrollo de la crítica contra los excesos verbalistas de los cultos, desarrollada desde todos los ángulos de la cultura española del momento, no existan quejas análogas verdaderamente específicas contra el conceptismo serio, sino tan sólo panegíricos del concepto. $Y$ ello es porque los conceptistas partían de una posición "oficial", garantizada en sus posibles exageraciones por testimonios tradicionales prestigiados en el arte clásico. Su actitud permanente era de ataque decidido contra cualquier descarrío de la ortodoxia. Los culteranos por el contrario reclamaban en su de- 
fensa una concepción revolucionaria, sobre la finalidad y los instrumentos del arte, sugerida por el gusto de los nuevos tiempos. Partian de una actitud de recelo, quizá con orgullosa conciencia, pero siempre en el fondo con la incertidumbre del renovador.

Por todo lo cual, Gracián, que considera al elegante Góngora de las composiciones menos culteranas el sereno enriquecedor del clasicismo, no se ve nunca en la necesidad de volver contra él los reproches de su crítica - bastante parca además- a los excesos verbales del cultismo. He aquí una de las contadas muestras de critica anticulterana que podrian apoyar la condición conceptista de la Agudeza:

«Esta diferencia hay entre las composiciones antigas y las modernas; que aquéllas todo lo echaban en concepto, y así están llenas de alma y viveza ingeniosa; éstas, toda su eminencia ponen en las hojas de las palabras, en la oscuridad de la frase, en lo culto del estilo, y así, no tienen tanto fruto de agudeza" ${ }^{76}$.

Atendiendo a las composiciones gongorinas censadas por Gracián en su Agudeza, no podría considerarse al poeta cordobés sino como un compañero de viaje del propio Gracián, un genial ingenioso, renovador y animador de las más clásicas esencias del lenguaje literario concebido como totalidad.

Con el estudio de la Agudeza y arte de ingenio culmina la historia de la doctrina conceptista en España, en el seno de esa tradición teórica que desde la Clasicidad ha venido haciendo de la dualidad res-verba una pieza clave en la definición de su concepción del arte. Posteriormente la denominación concepto se haria abundante y difusa. Su confusión podría ser el síntoma del extravío general del país en la segunda mitad del siglo XVII. En Gracián hemos encontrado continuas y anáiogas intuiciones básicas sobre la naturaleza, función y posibilidades del concepto, que constituian las constantes regulares de una tradición con plena conciencia de sí misma desde hacía cincuenta años, pero lo cierto es que sólo con él y desde su Agudeza ${ }^{77}$ este artificio —quin-

76 lbid., Vol. I, pp. 253-254.

77 Además de los centenares de citas del concepto, el interesantísimo uso de este término en la Agudeza proporciona curiosos términos derivados, algunos ya bastante usuales en otros autores, como conceptuoso/a, por ejemplo $I$, pp. 68, 74, 75, 84, 86 etc.; otros más raros, como conceptuosamente, I, p. 63; y otros definitivamente insólitos, como los verbos conceptear, I, pp. 66, 145, con sus formas conceptea, I, p. 270 , concepteado, I, p. 84, y conceptuar, 1, pp. 104, 114, con sus formas, como conceptuando, II, p. 253, etc..., etc. 
taesencia de la poética del ingenio-encontró su fijación definitiva, su imagen perdurable y su «arte» ${ }^{78}$.

78 Entre los estudios afines sobre la critica y las ideas literarias de Gracián no dedicados al sistema conceptista, recordaremos, V. Ramos, Literary ldeas of B. Gracián, Columbia, Univ. of Missouri, 1966; así como algunos artículos: J. M. de Cossío, Gracián, crítico literario, en «Boletín de la Biblioteca Menéndez Pelayom, V, 1923, pp. 69-74; E. Sarmiento, Clarificación de algunos pasajes capitales para la estética de B. Gracián, en "Bulletin Hispanique», XXXVII, 1935, pp. 27-56; y R. del Arco, Las ideas literarias de Gracián $y$ los escritores aragoneses, en “Archivo de Filología Aragonesa”, III, 1950, pp. 27-80. 